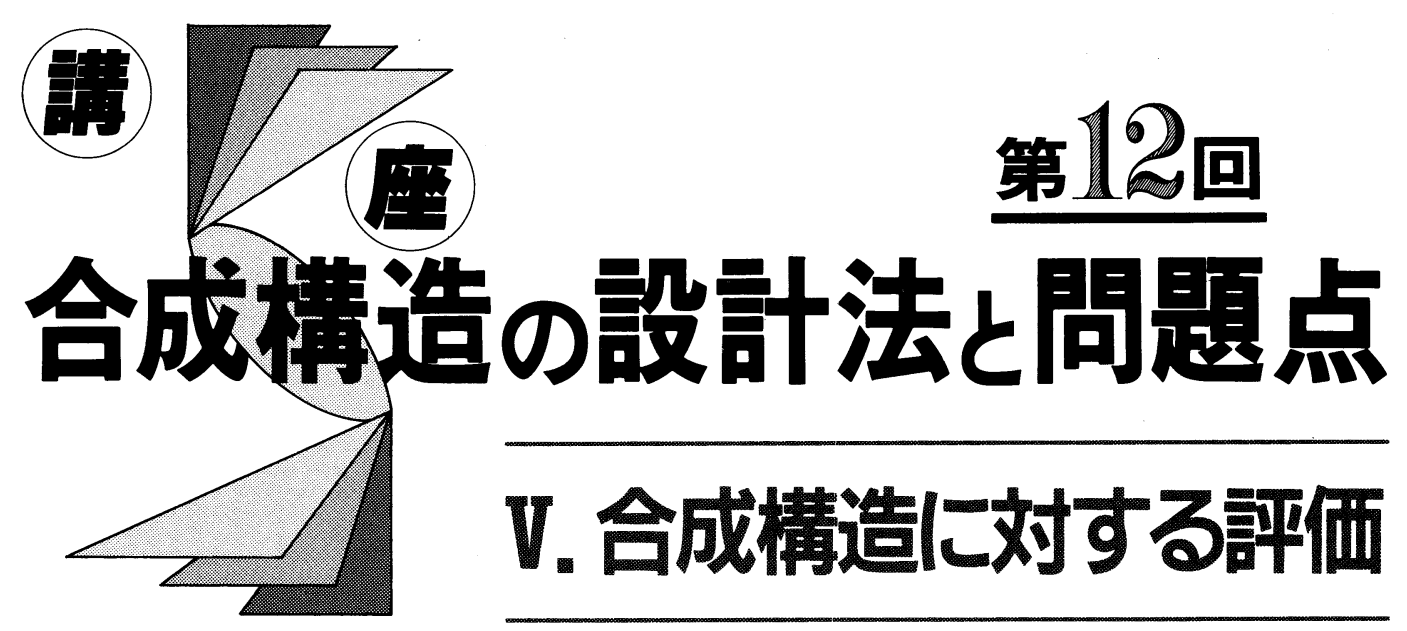

\title{
$\mathrm{V}-1$ 評定物件の審査例
}

1.はじめに

歴史は繰り返すと言うか, 1983 年 12 月に本誌で「コ ンクリートと合成構造」が特集されたが, ここに再び, 講座のかたちで紹介されることになった。本講座では, 著者陣は多くの現役に変わり, 最近の構法, 設計法につ いて新しい知見が述べられている。ただ，基本原理その ものには, ほとんど変わりがないと考えられる。

解説者としては, 与えられた本項の見出しについて, 合成構造全体に関する知識をもつ余裕のないままに執筆 することになったため，あるいは見当外れの記述をする かもしれないが，その点ご容赦を願いたい。

\section{2. 評定とは}

日本の建築物は, 法規である建築基準法・令に従って 建設され, 一般の建築物は, 特定行政庁によって,「確 認」と呼ばれる審査が行われる。同法・令内のとりきめ に適用外の場合は,「評定」と呼ばれる審查が行われ る。ときには特定行政庁の要請によって,「評定」に準 ずる審査が行われることもある。

評定は, 当該の建築物の構造設計に対しては, 構造耐 力上の安全性についての評定ということで, 主に(財)日本 建築センターで行われている。合成構造は, 同センター内 の高層建築物注 1), 鉄筋コンクリート構造注 ${ }^{2)}$, 鋼構

造注 3)，工業化住宅のコンクリート系構造注 4) に関す る 4 つの評定（または認定）委員会で扱われている。

「工業化住宅」では, 地上階数が 3 までで, たとえば 壁体が鉄筋コンクリート $(\mathrm{RC})$ パネル，壁体を結ぶは りが鉄骨 $(\mathrm{S})$ というような混合構造もあるが, 少数の 例も小規模なものなので，ここでは触れないでおく。

「高層建築物」では, 高さ $60 \mathrm{~m}$ を超える建築構造物 は，原子力関係を除き全部含まれている。

「鋼構造」では，鉄骨鉄筋コンクリート (SRC) 造な どの合成構造が含まれている。

「鉄筋コンクリート構造」では, $\mathrm{RC}$ 造を主役とし て, それに付隨する合成構造が, 少数であるが取り扱わ れている。

高さ $45 \mathrm{~m}$ から $60 \mathrm{~m}$ までの高さの建築物について は, 建築物の確認のいわば代行の「評価」と呼ばれる審 査が行われている。

昭和 63 年度 1 年間に評定が完了した物件について, 合成構造を中心としてその数をみると注 5), 「高層建 築物」では $\mathrm{SRC}$ 造が $4, \mathrm{~S}$ 造は 53 であり, 後者では, 地下部分は例外なく SRC 造であって，地上の一部に S $\mathrm{RC}$ 造が混用されているものが 14 含まれている。純粋 の $\mathrm{RC}$ 造は 13 である。「鋼構造」での「評価」の物件

注1) 高層建築物構造評定委員会 (委員長 : 加藤 勉 東京大学教 授)

注2) コンクリート構造評定委員会 (委員長 : 望月 重 武蔵工業 大学教授)

注3) 鋼構造評定委員会 (委員長 : 平野道勝 東京理科大学教授)

注4) 工業化住宅認定コンクリート系構造専門委員会 (委員 長 : 園部泰寿 筑波大学教授)

注5）昭和 63 年度構造評定委員会評定完了一覧, ビルディ ングレター, pp. 3〜21, 1989.7 
では, 上部構造が $\mathrm{SRC}$ 造のもの 6 , 鋼構造と混用のも の $16, \mathrm{RC}$ 造と混用のもの 3 であり, 鋼構造によるも のは 11 であった。「鉄筋コンクリート構造」では, S 造 との合成構造は 4 件扱われているが, いずれも軒高は $42 \mathrm{~m}$ 以下である。

昭和 62 年度から評定数が非常に増えているが, 高さ $45 \mathrm{~m}$ 以上の建築物での合成構造の採用のされ方は上記 のとおりである。概して事務所建築は鋼構造, ホテル建 築もだいたい鋼構造, 集合住宅は概してコンクリート系 構造ということができる。

\section{3. 高層建築の一般的耐震設計}

本項では, 最近の「高層建築物」にでてきた合成構造 の例を述べることとするが, その前に, $\mathrm{RC}$ 系の高層建 築物の一般的耐震設計の様子について触れることにす る。

\section{1 地 震入力}

高層建築物の 1 次固有周期は比較的長いので（まれに は高さ $60 \mathrm{~m}$ で 0.4 秒というのもあるが), 応答解析結 果が比較的そろうこともあり, 地震動の強さは, その最 高速度で基準化して, レベル 1 が $25 \mathrm{~cm} / \mathrm{s}$, レベル 2 が $50 \mathrm{~cm} / \mathrm{s}$ の 2 つのレ゙ルが設定されている。もちろ ん, 地域の地震活動性による低減は考慮に入れてもよい ことになっている。地震波形には, 代表的な実地震波 (たとえば El Centro 1940 波, Taft 1950 波など), 長 周期成分を含む実地震波, 地域性をもつ実地震波または 人工地震波が用いられる。

レベル 1 の地震に対応する静的地震力（設計用地震力 と呼んでいる）を，予備的に行った応答解析や現行の高 さ $60 \mathrm{~m}$ 以下の建築物についての耐震基準あるいは各種 文献を参考として定め, 許容応力度設計法にもとづく 1 次設計が行われる。

\section{2 耐震判定}

レベル 2 の地震に対する設計思想は設計者の自由であ るが, 構造体の崩壊機構あるいは降伏箇所の設定 (ある いは降伏をさせない部位の設定）は, 通常かなり明確に 意図され，構造体の 2 次設計が行われる。

このように設計された構造物は, 振動系モデルに置換 され, 所定の位置に地震波が入力されて応答解析が行わ れる。

応答解析結果は, 層レベルでの層せん断力, 層間変形 角, 層間変位, 転倒モーメント, 骨組モデルを使用した 場合は, 部材レベルの変形について算出される。

応答解析結果に対する耐震判定基準も設計者に負う が，おおかたのコンセンサスは，レベル 1 の地震波に対 しては, 層せん断力は設計用層せん断力以下あるいは弾 性限未満, 層間変形角は $1 / 200$ 以下, レベル 2 の地震波
に対しては, 層間変形角は $1 / 100$ 程度ということになろ う。各变形の塑性率に関しては, 基準とする変形の物理 的意味が構造種別および形式で異なるので一概には述べ にくいが, 層間变形角については, 当該層のある割合の 部材が降伏した時点の変形ということになる。この割合 については議論が分かれるところであり, その層に関係 する部材のどこかに初塑性ヒンジが発生するときとする か, あるいは, 後述の復元力特性の骨格折れ線での層降 伏相当の折れ点位置の变形がとられたりする。物理的な 意味合いからは, 前者のほうが明解であろう。

レベル 1 の地震波については弾性または弾塑性応答解 析が, レベル 2 の地震波については, 風荷重で決まる塔 類を除いては弾塑性応答解析が行われる。コンクリート 系の構造物では, ひびわれが入る関係で, レベル $1, レ$ ベル 2 ともに弾塑性解析が行われることが多い。

振動系は, 1 層 1 質点とした串形の並進形多質点系が もっとも標準的なものであるが, 同一階でも, 床面の連 絡がない場合は枝分かれした多質点系, 基礎構造等を共 有する場合は連結条件を考慮した併立多質点系, 林が剛 㦿とみなせない場合は質点を水平に床ばねで連結した多 質点系などが採用される (図-1参照)。また, 立体的あ るいは平面的な不整によってねじりが起きる場合は, 床 剛床仮定のもとに水平 2 方向, 鉛直軸回り回転 1 方向の 立体振動系が, 弾性あるいは弾塑性領域で設定される。

質点間を結ぶばねの復元力特性は, 等価せん断系また は等価曲げせん断系として考えられている。復元力特性 は層せん断力と層間変形角（あるいは層間变位）の関係 で設定され, 一般に折れ線形で表される骨格曲線之履歴 特性によって構成される。層せん断力之層間变位角の関 係は, 全架構 (平面架構の場合や凝似立体架構の場合も あるが), あるいは個々の架構や層単位の部分架構につ いて，1 次設計用地震力分布などによる水平力を加える 静的弾塑性增分荷重解析によって求められている。部材 置換は，材端に剛塑性回転ば秝を付したもの（図-2参 照), 材軸方向に部材を分割して考えるものなど, 種々 の方法で行われる。前者の場合では, 部材全体の材端に 働く逆対称モーメント $M$ に対する材端回転角の関係は,

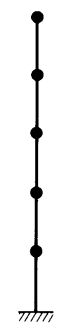

串形多質点系

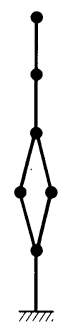

枝分かれ多質点系

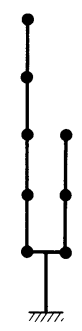

併立多質点系 


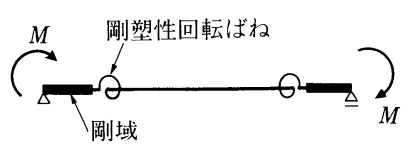

図-2 部材置換

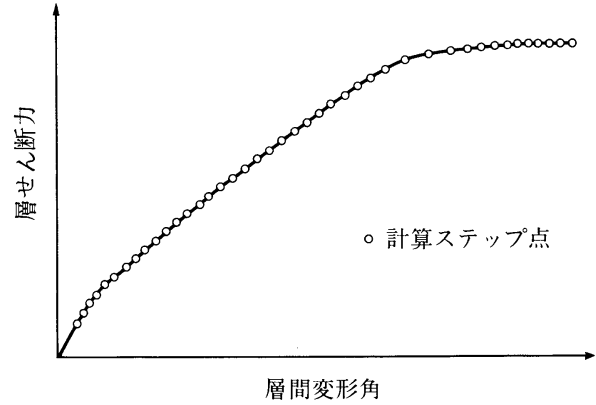

図-3 解析曲線

$\mathrm{RC}$ 部分については日本建築学会「鉄筋コンクリート構 造計算規準・同解説」（以下， $\mathrm{RC}$ 規準と呼ぶ）などに ある方法で求め, $\mathrm{S}$ 部分を累加し, さらに 3 折れ線系に 置換して決められる。部材の変形要素は, 水平荷重に対 しては，曲げおよびせん断変形，剛域の存在（あるいは はり柱接合部変形), 柱の軸方向変形などである。

等価曲げせん断系の場合は，建物全体としての転倒曲 げモーメントに対する柱の変形による全体回転の関係か ら曲げ剛性を定め，せん断については，等価の曲げ変形 分を層間変形角から差し引いてせん断層間変形角とし， それ之層せん断力との関係に置換して考えてゆく。

層せん断力一層間変形角曲線は図-3 のような曲線と なる。骨格曲線をそれをもとに決めるのは設計者の判断 によるが，別にルールが決まっているわけではない。た だし，情緒的にではなく，設計者が決めた方法に従え ば，だれでも同じかたちになるようになること，および 解析曲線になるべく合致することが要請されている。標 準的な（異論があるかもしれないが）3折れ線形をつく る方法を述べてみると, 第 1 折れ点は初期剛性線上に, ある層せん断力の値（たとえば当該層の部材の相当割合 の部材にひびわれが発生したときの値）の点に決める。 第 3 勾配線は, 増分荷重解析で相当の変形角が生じたと き（たとえば最大層変形角が $1 / n$ に達したとき）の解 析曲線上の接線とし，第 2 折れ点は, 折れ線系と解析曲 線が囲む面積が等しくなるようにして決める（図-4 参 照)。第 1 折れ点を初期剛性から落とした剛性線上に とったり, 第 2 折れ点に層間変形の靱性率の基準となる 性格（たとえばその層の部材に初めて降伏を始めた状態 とか）をもたせようとしたり，第 1 勾配に対する第 2 , 第 3 勾配の值を一率に決めてしまう等, 変化はさまざま

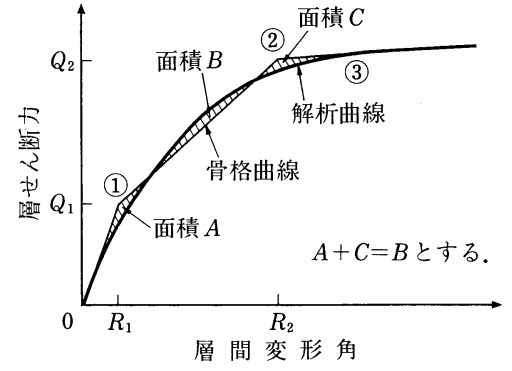

図-4 骨格曲線

である。また，ひびわれ発生点を無視するような，やや 荒っぽい考え方をする設計者もいる。

履歴特性については，剛性莪減型で過去の最大変形点 指向型（たとえば武田モデル）が選ばれることが多い が，その架構特性と合致することの見解が設計者に求め られる。

粘性隇衰は, 一般に内部減衰で初期または瞬間剛性比 例型とし, 1 次振動に対して減衰定数を 0.03 にとってい る。

なお，特別な耐震機構を組み込んだ壁体などを用いる 場合は, 構造実験で確証された力学的特性を解析モデル に採り入れて設計が行われる。

骨組レベルでの弾塑性応答解析は, $\mathrm{RC}$ 造では行われ ているが，SRC 造では習慣がなかったというべきか， 行われた例はないようである。

4. 審査例の紹介

\section{1 審 查 例 (1)}

この例は, 現時点で SRC 造としては最大の階数であ る地上 50 階建ての集合住宅である。図-5, 6 に基準階

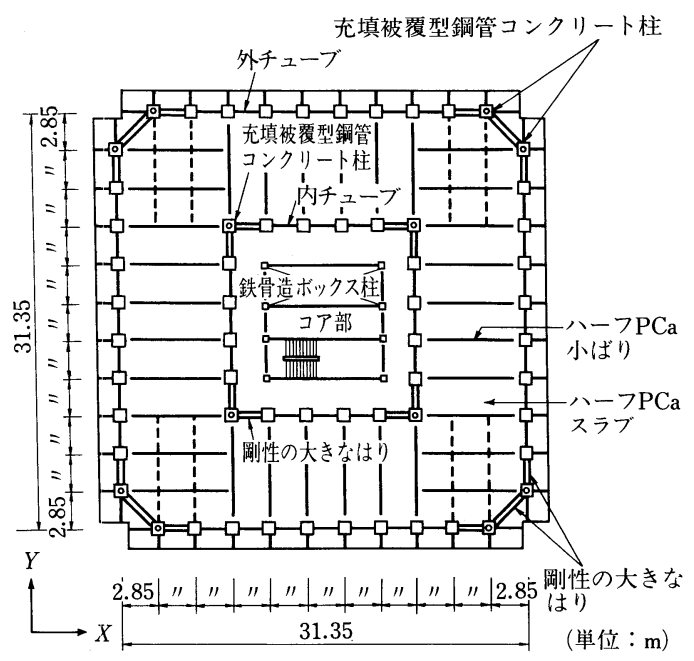

図-5 例 (1) の基準階伏図 


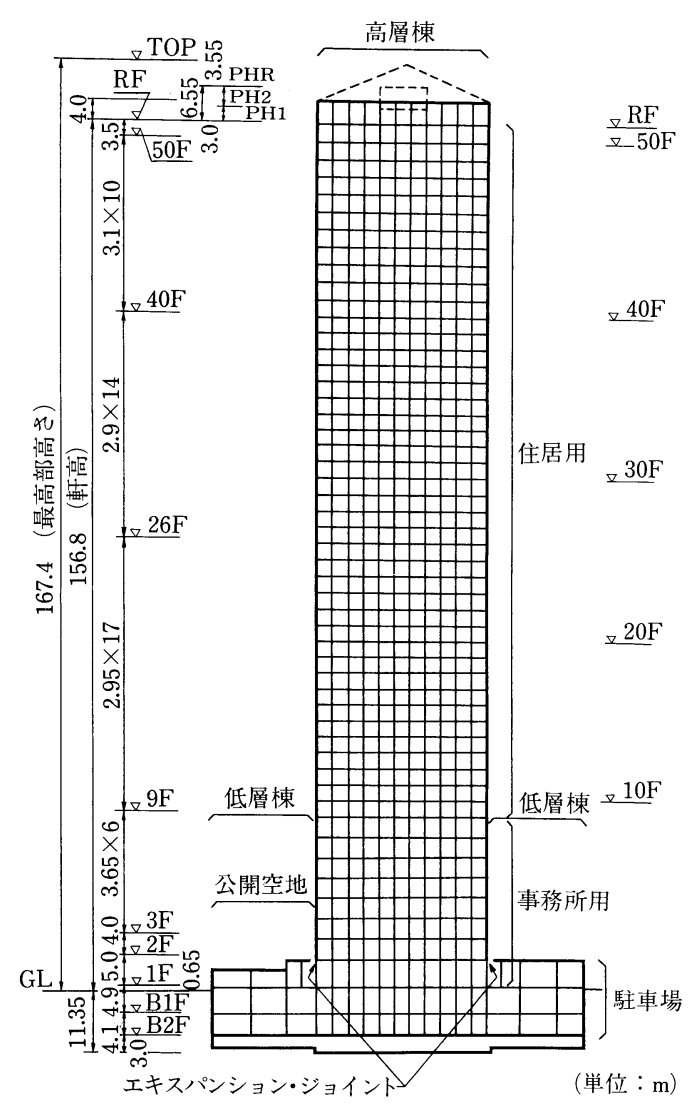

図-6 例 (1) の軸組図

\begin{tabular}{|c|c|c|}
\hline 内チューブ隅柱 & $X$ 方向柱 & $Y$ 方向柱 \\
\hline 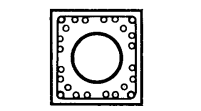 & 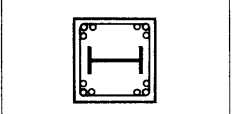 & \\
\hline $1100 \times 1100$ & $1000 \times 1000$ & $1000 \times 1000$ \\
\hline $12-\mathrm{D} 41+12-\mathrm{D} 41$ & $12-\mathrm{D} 35$ & 12-D 35 \\
\hline $609.6 \phi \times 40$ & $\mathrm{H}-708 \times 306 \times 19 \times 28$ & $\mathrm{H}-708 \times 306 \times 19 \times 28$ \\
\hline
\end{tabular}

(注) コンクリート: $F_{c \max }=360 \mathrm{kgf} / \mathrm{cm}^{2}$

主筋：SD 40

鋼材: SM $50 \mathrm{~A}, \mathrm{SCW} 50-\mathrm{CF}$

図-7 例 (1) の 1 階柱断面（鋼種旧 JIS 表示）

伏図と軸組図を示す。建物の軒高は $156.8 \mathrm{~m}$, 最高部高 さは $167.4 \mathrm{~m}$ で, 基準階平面は隅切りのある 1 辺 31.35 $\mathrm{m}$ の正方形である。架構は外周とコア回りのダブル チューブのラーメン構造である。外周の隅切り部の柱お よびコア回りの隅柱は充填被覆型鋼管コンクリート造, 他の柱は強軸を構面方向と直角方向においた $\mathrm{H}$ 形鋼を 内蔵した SRC 造とし, 大ばりは通常の SRC 造であ
り, チューブ架構の隅角部は, とくに強化された部材を 用いている。チューブ架構間の床組みは半プレキャス卜 (PCa) の床板および小ばりを用いて床部分の場所打ち コンクリートにより合成床組みとしている。はりと柱 は, 鉄骨に鉄筋を先付けしておいて建方し, コンクリー トを場所打ちして構築する。図-7に 1 階の柱の断面を 示す。

\section{2 審 査 例 (2)}

この例は地上 40 階建ての集合住宅で，図-8, 9 に基 準階伏図と軸組図を示す。建物の軒高は $119.15 \mathrm{~m}$, 最 高部高さ $119.50 \mathrm{~m}$, 基準階平面は隅切りのある $29.6 \times$ $36.6 \mathrm{~m}$ の長方形である。主要部材断面は図-10 に示す ように $\mathrm{SRC}$ 造で, 床が PCa 板または半 $\mathrm{PCa}$ 板による 合成床である。この建物の特徵は, 外周部 1 スパンを厚 み 200 の合成床板とし, 外周ばりのせいを低くした点に あり, 外周ゾーンのはりをなくす, あるいは非常にせい を小さくするタイプの計画のものに先鞭をつけたもので ある。外周床板は， $X$ 方向に地震力が作用する場合に $Y$ 方向ばりにねじりを与えるため, 十字またはト字形

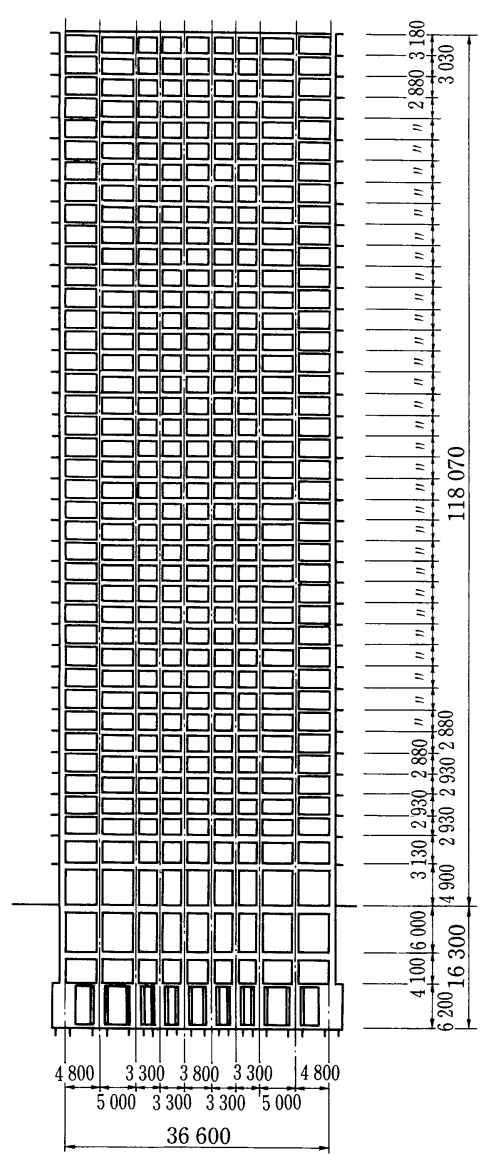

図-8 例 (2) の軸組図 


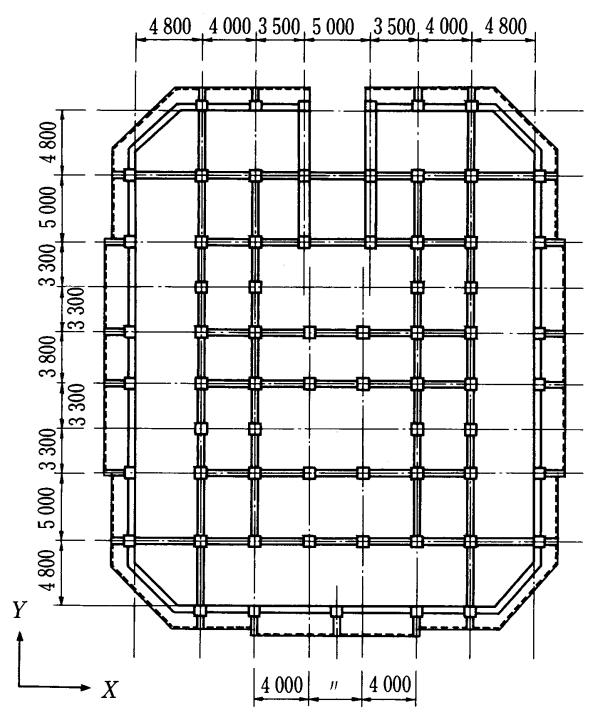

図-9 例 (2) の基準階伏図
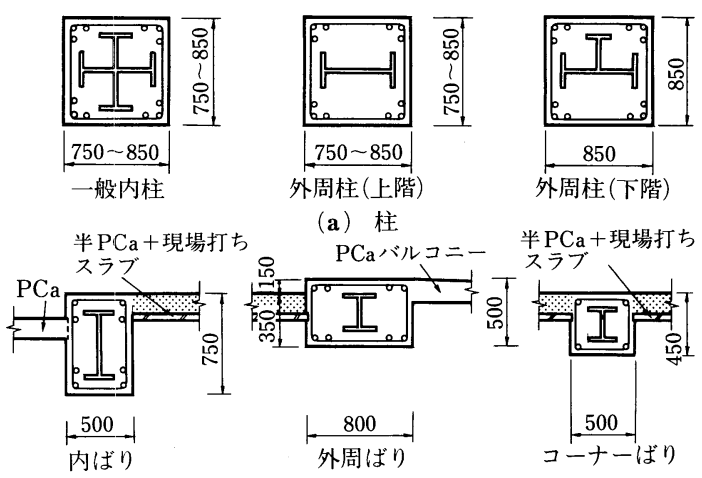

(b) 大ばり
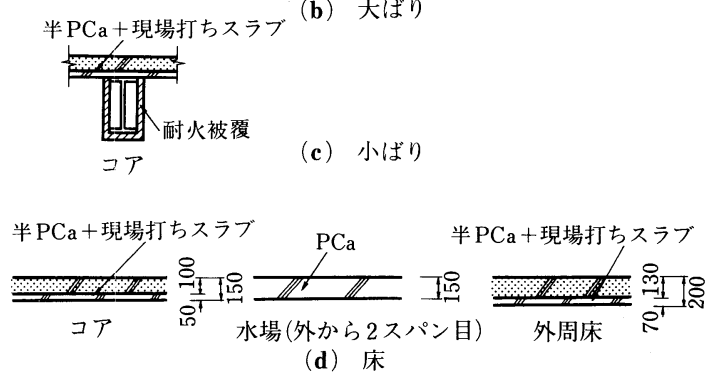

図一10 例 (2) の主要部材断面
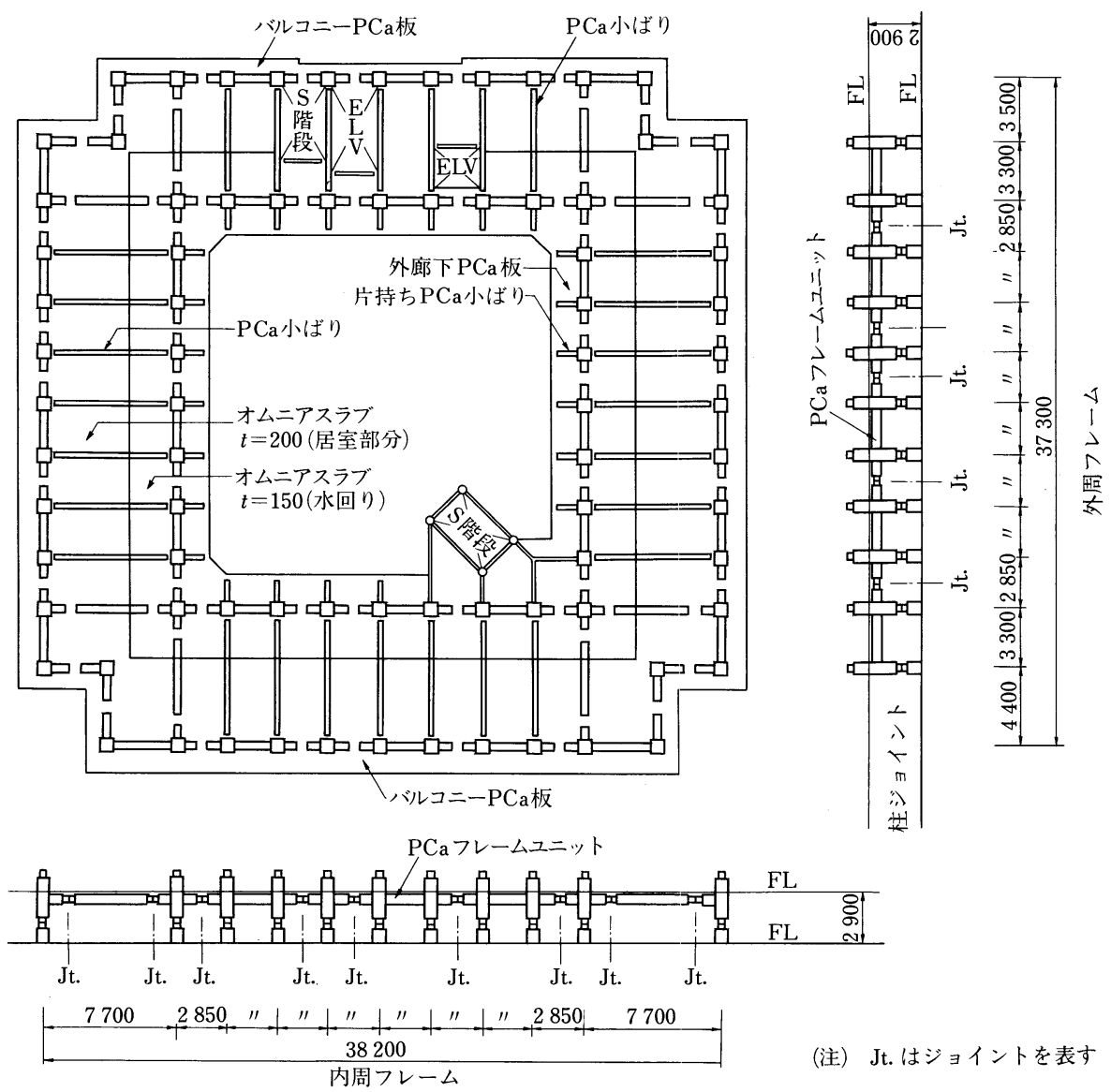

（注）Jt.はジョイントを表す

図-11 例 (3) の基準階平面之部材分割図 
の部分架構による構造実験が行われ，安全性の検討がな されている。

\section{3 審 查 例 (3)}

この例は, 地上 37 階建ての集合住宅である。図-11

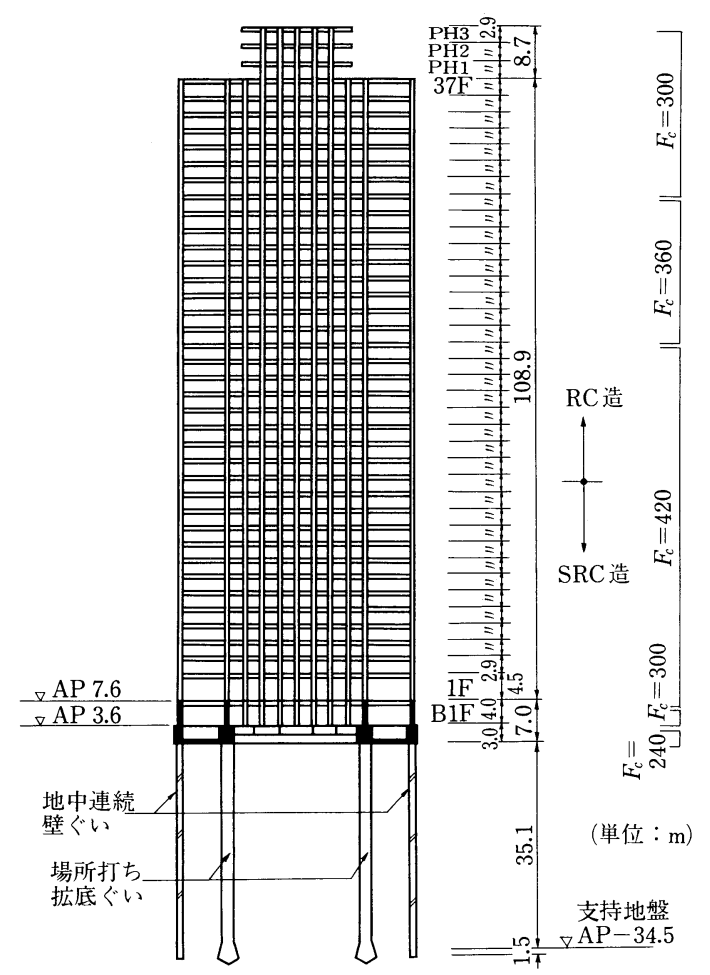

図-12 例 (3) の軸組図
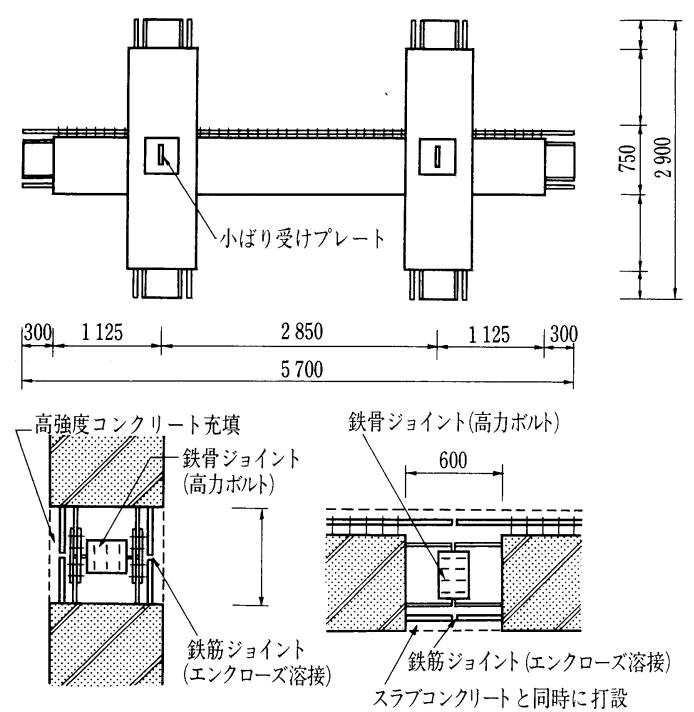

柱・柱ジョイント

はり・はりジョイント(はり中央)

図-13 例 (3) の $\mathrm{PCa}$ ユニット

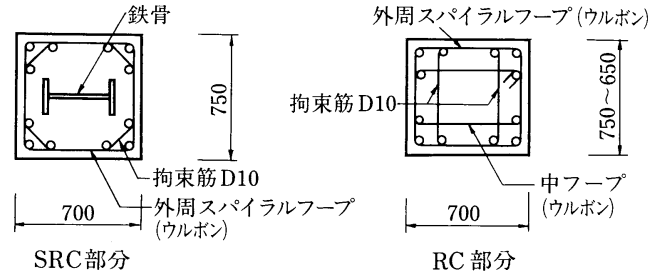

(a) 柱標準断面

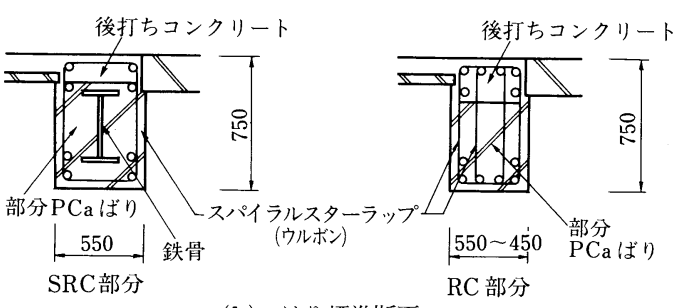

（b）はり標準断面

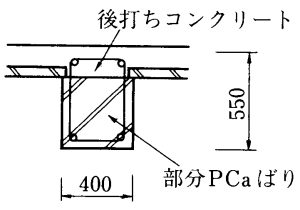

$7.7 \mathrm{~m}$ スパン

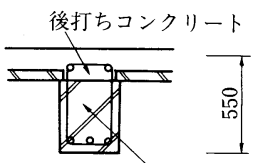

|350」部分 $\mathrm{PCa}$ ばり $6.8 \mathrm{~m}$ スパン (c) 小ばり断面

図-14 例 (3) の部材断面図

に基準階平面と部材分割図を, 図一12 に軸組図を示す。 建物の軒高は $109.0 \mathrm{~m}$, 最高部高さは $111.8 \mathrm{~m}$, 基準階 平面は $38.2 \times 37.3 \mathrm{~m}$ の長方形の隅を欠いた形で，平面 中央に $22.8 \mathrm{~m}$ 角の正方形の吹抜けがある。地階から 13 階柱中央までが $\mathrm{SRC}$ 造，それより上は $\mathrm{RC}$ 造で，それ ぞれ純ラーメンのダブルチューブ構造となっている。構 築構法は積層工法で, はり中央および柱中央で切り離し た十字あるいはサ字形の PCa 部材（図-13 参照）を集 成して架構を構築する。床板は片持ち部分が PCa 板,

一般部分は半 $\mathrm{PCa}$ 板を使用した合成床板である。部材 断面形を図-14 に示す。設計基準強度 $420 \mathrm{kgf} / \mathrm{cm}^{2}$ の 高強度コンクリートを使用しており, 柱接合部では圧入 により充填を行う。はり柱接合部周辺の充填性調查と併 せて, 圧入の施工実験が行われた。

\section{4 審 查 例 (4)}

この例は，地上 40 階建ての集合住宅である。図-15 に基準階平面図之部材分割図を, 図一16 に軸組図を示 す。建物の軒高は $130.2 \mathrm{~m}$, 最高部高さ $140.3 \mathrm{~m}$, 基準 階平面は $56.6 \times 45.0 \mathrm{~m}$ の長方形で, 平面中央に $32.4 \times$ $27.0 \mathrm{~m}$ の吹抜けがある。地階から 26 階床までが SRC 造，その上は $\mathrm{RC}$ 造で，それぞれ純ラーメンのダブル チューブ構造となっている。 SRC 造部分は, 大ばり， 小ばり, 床が半 PCa 材を使用した合成部材, 柱および はり柱接合部は場所打ちコンクリートによって構成され 
$\mathrm{PCa}$ ばりの柱(あるいははり)

への接合方法

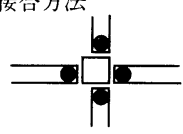

•フランジ溶接, ウェブ高力ボルト接合,

はり主筋はエンクローズ溶接を示す

○ウェブだけ高力ボルト接合を示す

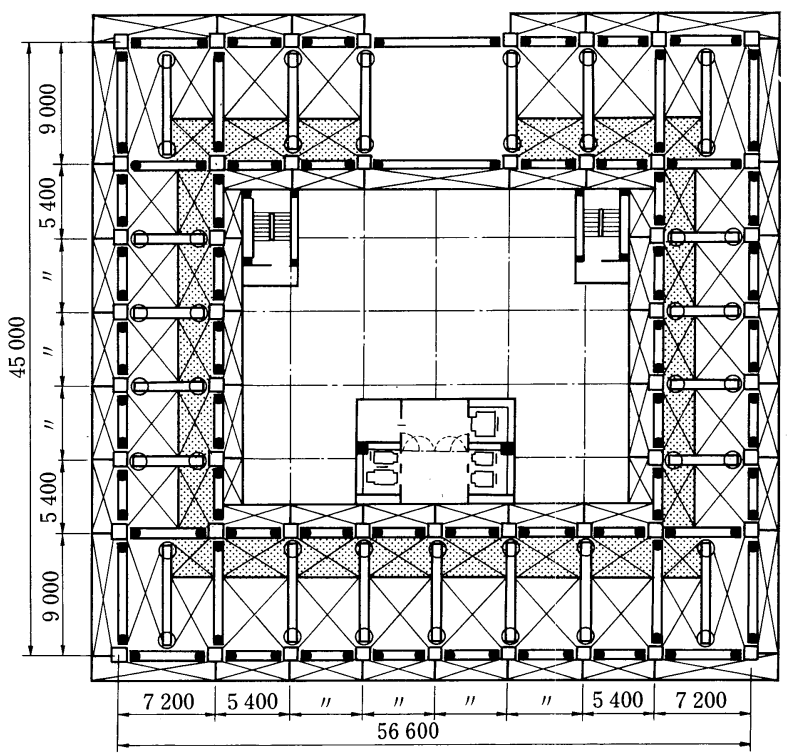

図-15 例 (4) の基準階平面と部材分割図

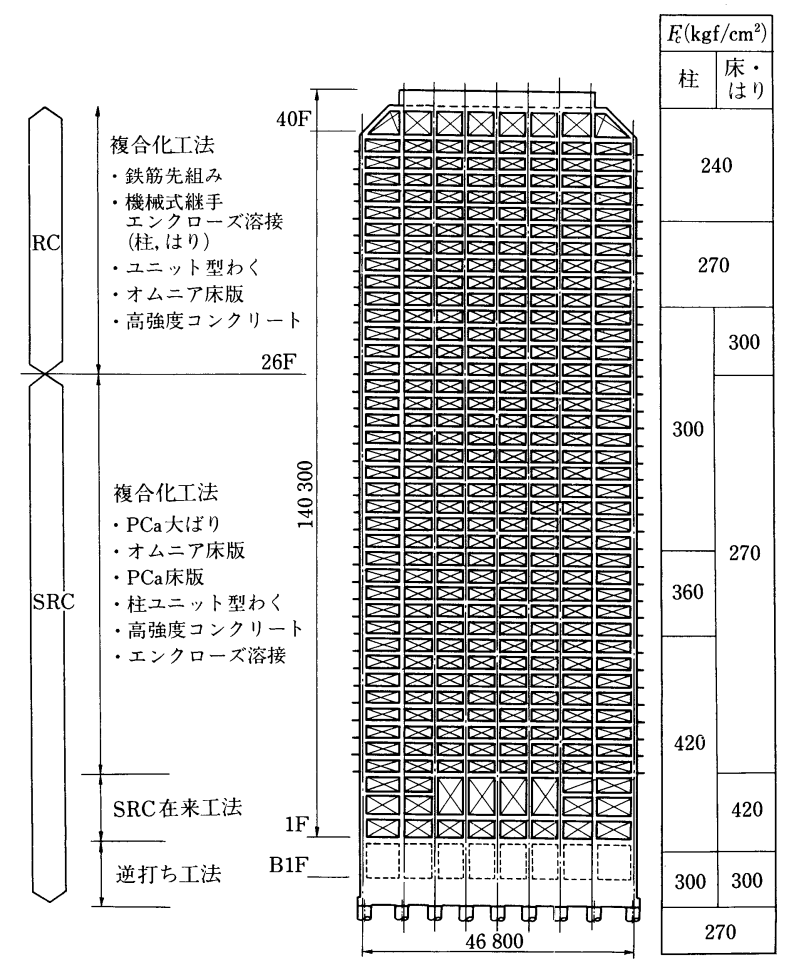

図-16 例 (4) の軸組図 


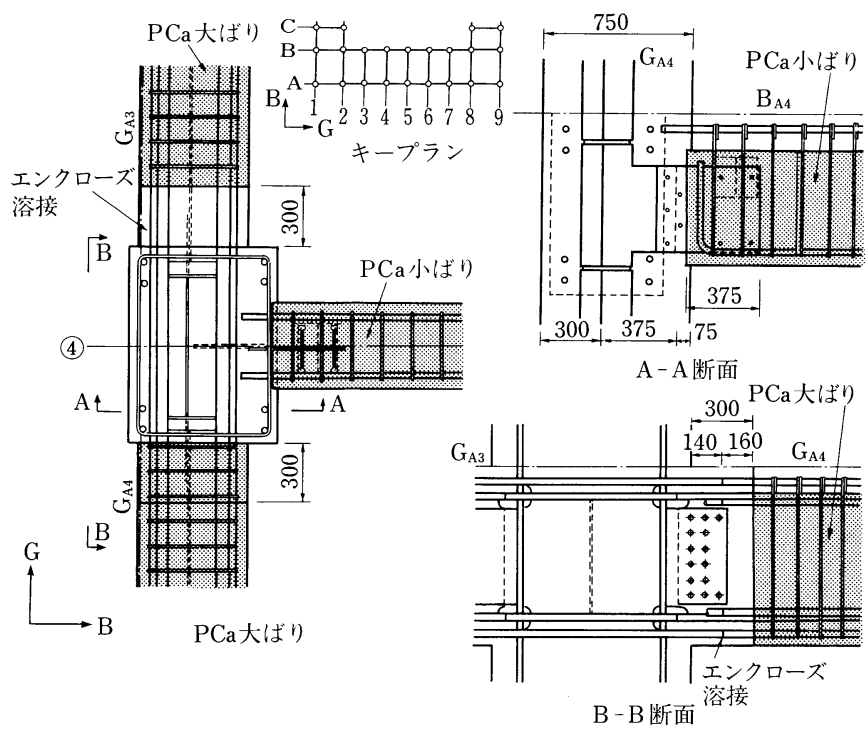

図-17 例 (4) の PCa 部材接合部

ている。はりはいずれも 1 スパンのもので，図-17に示 すように，はり柱接合部周辺で柱と接合される。この例 では，大ばりの主筋継手が部材としての降伏領域にある ので, 慎重さを要する。はり柱接合部内のほうが望まし いと考えられる。

\section{5 審 查 例 (5)}

この例は地上 36 階建てのホテルで，図-18 に基準階 伏図, 図-19 に軸組図を示す。建物の軒高は $112.8 \mathrm{~m}$, 最高部高さは $121.0 \mathrm{~m}$, 基準階平面は正方形の隅切りを した形で，対角の長さは $27.0 \mathrm{~m}$ である。中央に $8.8 \mathrm{~m}$ 角のコアがある。コアは $\mathrm{SRC}$ 造の有・無開口の鋼板入

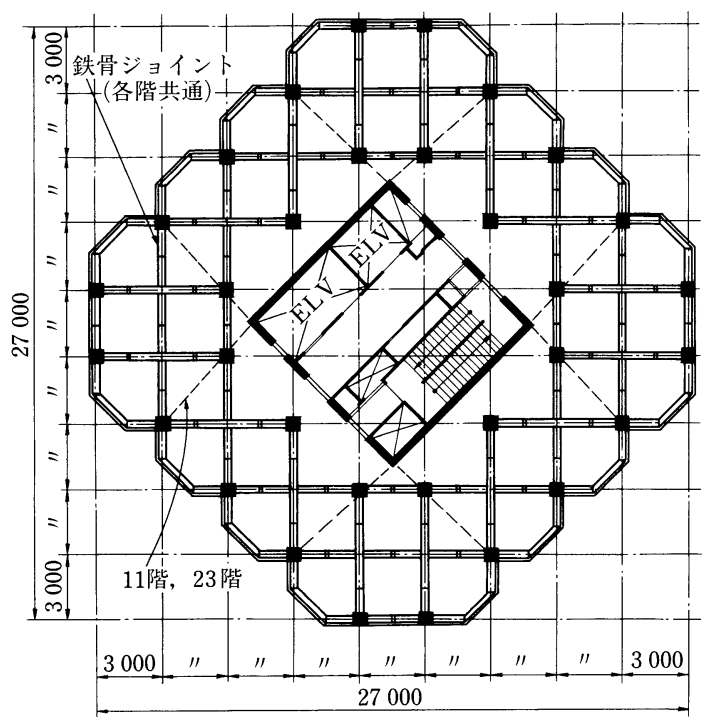

図-18 例 (5) の基準階伏図

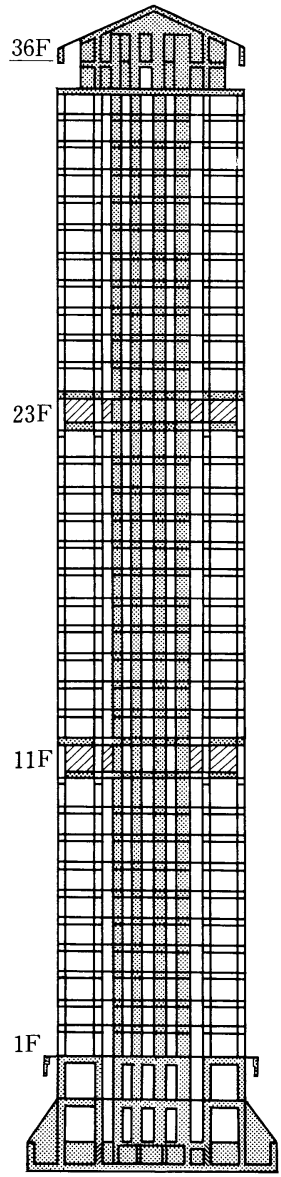

図-19 例 (5) の軸組図 
り壁体，コア周辺の架構は $\mathrm{S}$ 造純ラーメンである。1 11 階, 23 階ではコア隅角部から鋼板壁によりコアと周辺 架構が結ばれ，コアを中心とするスーパーフレームが構 成されている。算定されたコア部分の設計用地震力によ る曲げモーメント図を図-20に示す。上記のはりとして 働く鋼板壁による曲げ戻しにより, 11 階と 23 階では大 きな逆せん断力が働いている。この部分に関して地震力 がコアの壁面の 1 辺の方向に働く場合, コアのウェブに
あたる壁体よりもむしろフランジにあたる地震力に直交 方向の壁体において, せん断流れによって, 壁体のせん 断応力度は非常に大きな值となる。そのためもあり, 当 初, コアは RC 造の計画であったが, 鋼板入り $\mathrm{SRC}$ 造 となった。

\section{6 番 査 例 (6)}

この例は, 鉄骨架構に平鋼板内蔵 PCa 造耐震壁を組 み入れた例である。建物は, 地上 18 階建てのホテルで,

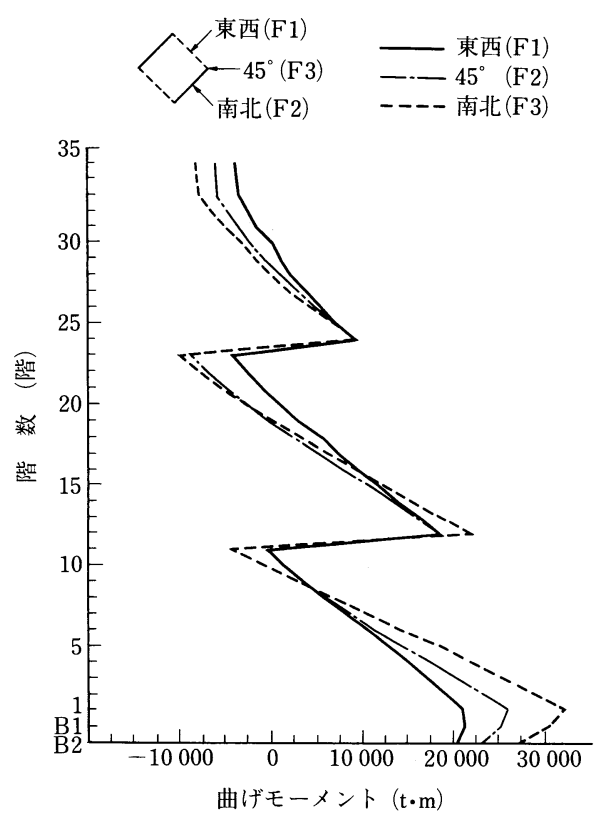

図-20 例 (5) のコア部分曲げモーメント図

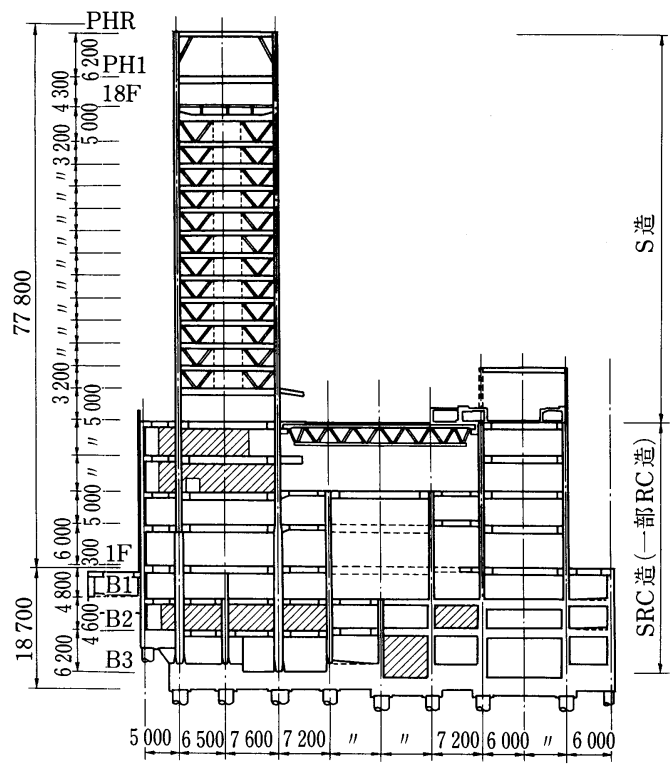

図-22 例 (6) の軸組図

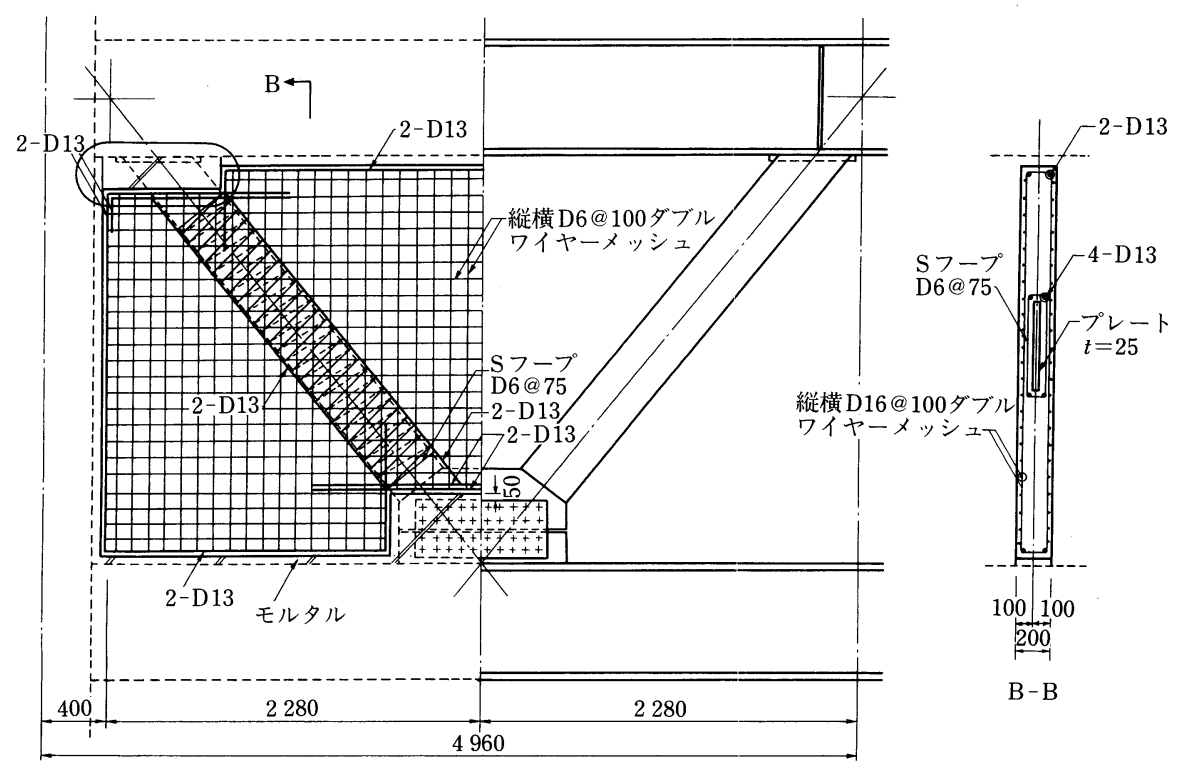

図-21 例 (6) のPCa 耐震壁 


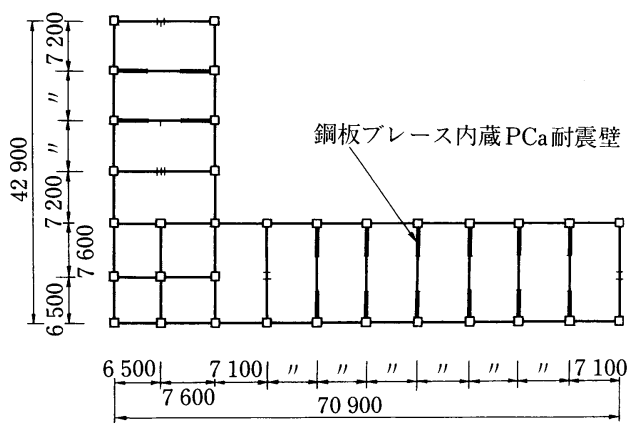

図-23例 (6) の基準階平面図

5 階床以下は $\mathrm{SRC}$ 造, 5 階柱以上は上記の $\mathrm{S}$ 造である

(図-22, 23 参照)。而震壁の平鋼板は, 図-21 に示す ように V 形で, 座屈に対抗するため, 拘束鉄筋で取り 囲まれている。耐震壁の剛性は, 実験結果にもとづき, コンクリートの協力幅（壁厚の 3 倍）を考え，降伏耐力 は, 平鋼板の座屈を考えないときの材料強度による耐力 によっている。耐震壁回りの崩壊機構は, 耐震壁を結ぶ $\mathrm{S}$ ばりの耐震壁内側端の曲げ降伏となっている。

このタイプの耐震壁では, 平鋼板と壁体コンクリート との付着を切るものもある。

\section{7 審 查 例 (7)}

この例は, 鉄骨架構に平鋼板内蔵 PCa 造耐震壁を組 み入れたもので, 他の物件でも用いられている。建物は 19 階建ての事務所で, $\mathrm{S}$ 造である (図-24, 25 参照)。 耐震壁は張り間方向だけに配置されている。耐震壁の平 鋼板は, 図-26に示すように, 壁の見付け面について, ひし形状の斜材と水平断面端部の鉛直材からなる。鉛直

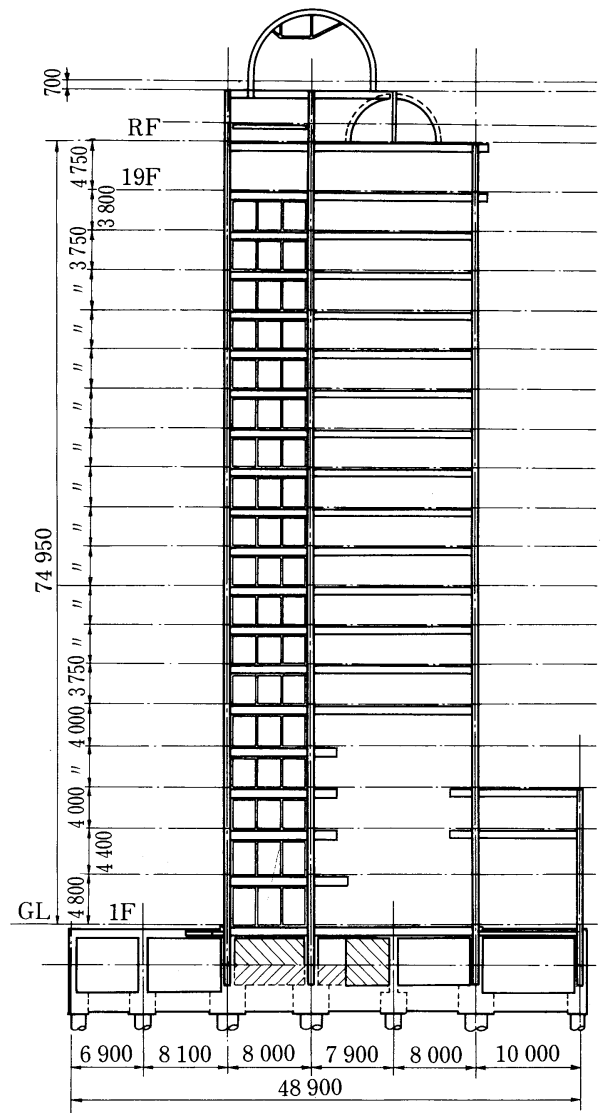

図-25例 (7) の軸組図

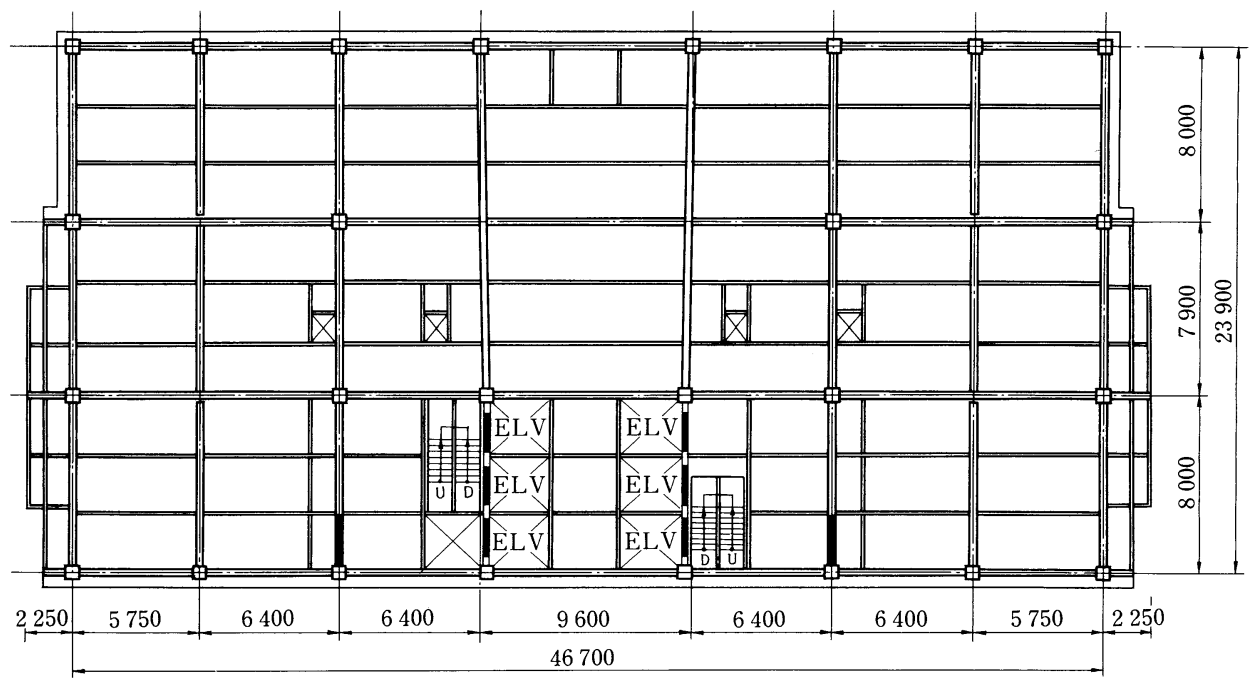

図-24 例 (7) の基準階伏図 


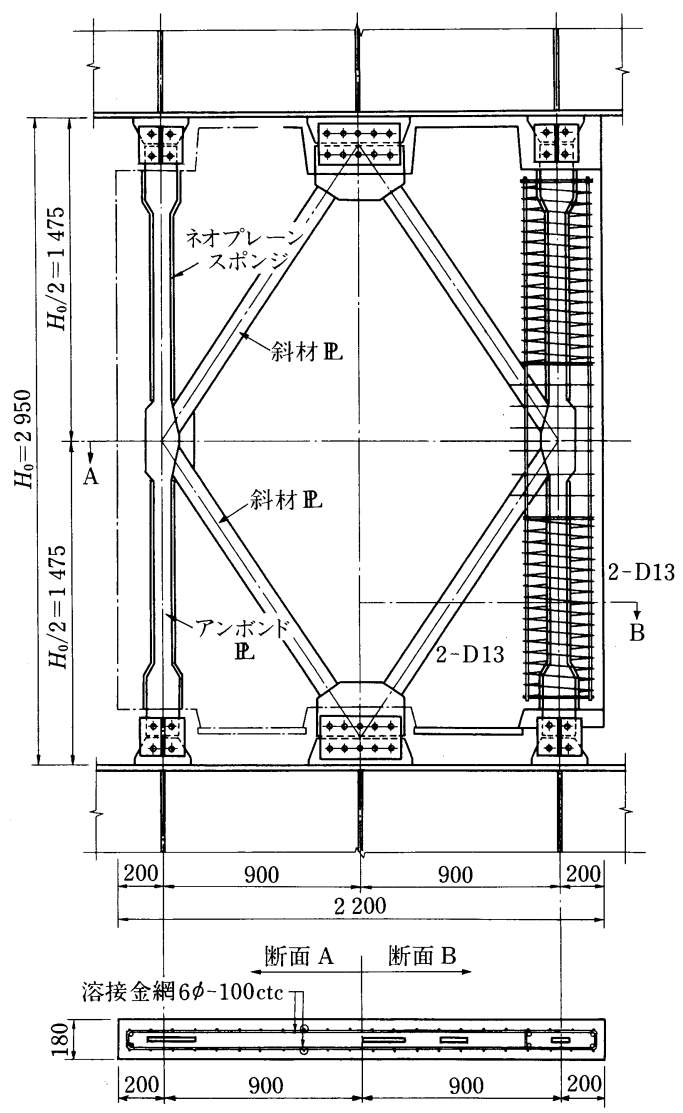

図-26 例 (7) の耐震パネル

材はコンクリートと縁が切ってあり，その周辺にスパイ ラルの座屈に対抗するための拘束筋が配置されている。 意図されている機構は，耐震壁の上下端で左右一対の鉛 直材が引張りおよび圧縮降伏して回転する。つまり, 壁 体の上下端の個材曲げに対して回転降伏し，壁体内に入 るせん断力を制御するとともに, 勒性を生み出そうとす るものである。壁体の剛性評価には, 実験結果を採り入 れた半実験式を用いている。架構の崩壊形は, 耐震壁を 含む箇所では, 耐震壁の回転形降伏がはりの降伏に先行 して起きるかたちとなっている。

一一解説 : 園部泰寿 (筑波大学)

\section{$\mathrm{V}-2$ 今後の展望}

前述の特集で, 谷 資信先生が「合成構造の将来像」 之題し, 各論の詳論ののち, なかなか現実離れした将来
像が描けないと述べられている。筆者としては，とても 卓拔な展望がもてないが, しかもたぶん，いずれまた見 直しが行われるであろうが, ともかく見通しらしいもの を述べてみる。

現在の建設界の好景気がそういつまでも続くとは思え ないが, しばらくは労㗢力の不足, 工期の保持などの理 由から, 部材をいわゆる半 $\mathrm{PCa}$ 化し, 場所打ちコンク リートで全体を一体化する構法が広まるものと思われ る。

高層建築物では, 集合住宅の例でダブルチューブ型が 多くなっている。中央コア型の混合構造の構造システム の開発も期待できよう。

構造材料についてみると, 住宅も 1 戸当りの面積が大 きくなり, 高層建築物もますます高層化してきており, それにともない, 材料の高性能化が進みつつある。鋼材 では TMCP 鋼が出現し, 極厚の SM 58 クラスが使用 されるようになり, 新素材・新材料利用技術開発の建設 省総合プロジェクトでは, さらに高性能の降伏比が高く ない鋼材が取り上げられることになろう。コンクリート に関しては, 民間における高層 RC 造の設計・施工技 術開発の結果, 設計基準強度が $F_{c}=480 \mathrm{kgf} / \mathrm{cm}^{2}$ のコ ンクリートも使用されている。 SRC 造では $F_{c}=420$ $\mathrm{kgf} / \mathrm{cm}^{2}$ までが使用されているが, 充填性を考え, 柱 に圧入工法がとられたりしている。通称「New RC」 の建設省総プロでは，コンクリートの圧縮強度が 1.0 $\mathrm{tf} / \mathrm{cm}^{2}$, 鉄筋が SD 100 クラスまでという夢の $\mathrm{RC}$ 造 が扱われており, 関連して, 高強度コンクリートの施工 実験が行われたりしている。前述の新素材総プロでは, 高強度の炭素, アラミド, ガラス等の短繊維や連続繊維 のFRP 棒材による補強コンクリートの利用技術が扱わ れている。人工軽量骨材による軽量コンクリートも, 現 行の $F_{c}=270 \mathrm{kgf} / \mathrm{cm}^{2}$ から $360 \mathrm{kgf} / \mathrm{cm}^{2}$ ぐらいまでは 使用できるようになると思われる。

これらの材料の高性能化にともない, 合成構造にも, 対応した変化が生ずると考えられる。

合成棈造では, コンクリートと鋼材の長所を最大限に 生かし, かつ力学的機構を意図的に組み込むことができ る。たとえば長大部材において, 鋼材だけで一部分の軽 量化をはかるとか, たわみ防止にある特定部を $\mathrm{SRC}$ 造 または $\mathrm{RC}$ 造にするとか, 拘束されたコンクリートで 鋼材の座屈止めをする, あるいはその逆で, 鋼材による 拘束でコンクリートの勒性を確保するなど, 現在でも 種々の技術開発が発表されてきており,さらに発展が期 待できよう。

一一解説 : 園部泰寿（筑波大学） 